\title{
Boron-modified Polysilylcarbodi-imides as Precursors for Si-B-C-N Ceramics: Synthesis, Plastic-forming and High-temperature Behavior
}

\author{
Markus Weinmann, ${ }^{1 *}$ Rainer Haug, ${ }^{1}$ Joachim Bill, ${ }^{2}$ Mark de Guire, ${ }^{1,3}$ Fritz \\ Aldinger ${ }^{1,2}$ \\ ${ }^{1}$ Max-Planck-Institut für Metallforschung, Pulvermetallurgisches Laboratorium, Heisenbergstraße 5, \\ D-70569 Stuttgart, Germany \\ ${ }^{2}$ Universität Stuttgart, Institut für Nichtmetallische Anorganische Materialien, Heisenbergstraße 5, D-70569 \\ Stuttgart, Germany \\ ${ }^{3}$ Department of Materials, Science and Engineering, Case Western Reserve University, 10900 Euclid \\ Avenue, Cleveland, OH 44106-7204, USA
}

The synthesis, by two different reaction pathways, of boron-modified polysilylcarbodi-imides of general type $\left\{\mathrm{B}\left[\mathrm{C}_{2} \mathrm{H}_{4} \mathrm{Si}(\mathrm{R}) \mathrm{NCN}\right]_{3}\right\}_{n} \quad(\mathrm{R}=$ singly bonded organic ligand) and the plasticforming and the thermal behavior of these polymers are described. Compounds $\left\{\mathrm{B}\left[\mathrm{C}_{2} \mathrm{H}_{4} \mathrm{Si}(\mathrm{R}) \mathrm{NCN}\right]_{3}\right\}_{n}\left[2 \mathrm{a}, \mathrm{R}=\mathrm{H} ; 2 \mathrm{~b}, \mathrm{R}=\mathrm{CH}_{3}\right.$; $\left.2 c, R=(N C N)_{0.5}\right]$ can be obtained by treatment of the vinyl-substituted polysilylcarbodi-imides $\left[\left(\mathrm{H}_{2} \mathrm{C}=\mathrm{CH}\right)(\mathrm{R}) \mathrm{SiNCN}\right]_{n}\left[\mathbf{1 a}, \mathrm{R}=\mathrm{H} ; \mathbf{1 b}, \mathrm{R}=\mathrm{CH}_{3}\right.$; $1 \mathrm{c}, \mathrm{R}=(\mathrm{NCN})_{0.5}$ ] with borane dimethylsulfide $\mathrm{BH}_{3} \cdot \mathrm{S}\left(\mathrm{CH}_{3}\right)_{2}$. The polysilylcarbodi-imides 1a-1c themselves are accessible via the reaction of vinyl-substituted chlorosilanes $\left(\mathrm{H}_{2} \mathrm{C}=\mathrm{CH}\right)$ (R) $\mathrm{SiCl}_{2}$ with cyanamide $\mathrm{H}_{2} \mathrm{~N}-\mathrm{C} \equiv \mathrm{N}$ in the presence of pyridine or by a non-oxide sol-gel process of vinylated chlorosilanes and bis(trimethylsilyl)carbodi-imide, $\quad\left(\mathrm{H}_{3} \mathrm{C}\right)_{3} \mathrm{SiN}=\mathrm{C}=\mathrm{N}$ $\mathrm{Si}\left(\mathrm{CH}_{3}\right)_{3}$. In the second method for the synthesis of 2a-2c, hydroboration of vinylsubstituted chlorosilanes $\left(\mathrm{H}_{2} \mathrm{C}=\mathrm{CH}\right)(\mathrm{R}) \mathrm{SiCl}_{2}$ with borane dimethylsulfide, borane trimethylamide or borane triethylamide to yield the tris[(chlorosilyl)ethyl]boranes $\mathrm{B}\left[\mathrm{C}_{2} \mathrm{H}_{4} \mathrm{Si}(\mathrm{R}) \mathrm{Cl}_{2}\right]_{3}$ (3a, $\mathrm{R}=\mathrm{H} ; 3 \mathrm{~b}, \mathrm{R}=\mathrm{CH}_{3} ; 3 \mathrm{c}, \mathrm{R}=\mathrm{Cl}$ ) is followed by treatment of the as-obtained compounds with bis(trimethylsilyl)carbodi-imide, which results in the formation of the hydroborated polysilylcarbodi-imides 2a-2c. The thermogravimetric behavior of the polymers 1a-1c and $2 a-2 c$ up to $2300^{\circ} \mathrm{C}$ is reported. It is shown that boron-

* Correspondence to: M. Weinmann, Max-Planck-Institut für Metallforschung, Pulvermetallurgisches Laboratorium, Heisenbergstraße 5, D-70569 Stuttgart, Germany.

Contract/grant sponsor: Deutsche Forschungsgemeinschaft (DFG). Contract/grant sponsor: Japan Science and Technology Corporation (JST). modified polysilylcarbodi-imides are suitable precursors for the preparation of dense bulk ceramics. Therefore, the preparation of green bodies of the hydroborated polysilylcarbodiimides 2a-2c by plastic forming (PF) is described. A series of experiments points to the fact that the microstructure of the as-obtained ceramic monoliths obtained by subsequent thermolysis of the plastic-formed green bodies is strongly influenced by the conditions during plastic forming. (C) 1998 John Wiley \& Sons, Ltd.

Keywords: precursor; ceramic; thermolysis; silicon; carbodi-imide; boron; hydroboration; plastic forming

Received 1 July 1997; accepted 1 August 1997

\section{INTRODUCTION}

Boron-containing polycarbosilazanes, ${ }^{1-4}$ carboncontaining polyborosilazanes ${ }^{5-7}$ and silylated borazine derivatives ${ }^{8-12}$ have been shown to be excellent precursor molecules to ceramic composite materials in the quaternary system $\mathrm{Si}-\mathrm{B}-\mathrm{C}-\mathrm{N}$. These molecules in general consist of $\mathrm{Si}-\mathrm{N}$ skeletons, which are more or less crosslinked by $\mathrm{B}, \mathrm{B}-\mathrm{N}, \mathrm{B}-\mathrm{C}$ or borazine units, carrying different substituents bonded to the silicon centers. The synthesis of the $\mathrm{Si}-\mathrm{B}-\mathrm{C}-\mathrm{N}$ precursors is commonly realized either by reaction of chlorosilanes or chloroboranes with amines or ammonia, ${ }^{1-7}$ or by dehydrogenative coupling reactions of silazanes with derivatives of borane or of borazine. ${ }^{8-12}$

The polymeric precursors are then transformed 
into amorphous $\mathrm{Si}-\mathrm{B}-\mathrm{C}-\mathrm{N}$ ceramic materials by subsequent thermolyses (for selected reviews, see $\operatorname{Refs}^{13-16}$ and literative cited therein). Due to the considerable sensitivity of these compounds towards moisture and oxygen, the ceramization step has to be performed in an inert-gas atmosphere. In some cases, the as-obtained $\mathrm{Si}-\mathrm{B}-\mathrm{C}-\mathrm{N}$ ceramic composites exhibit excellent thermochemical properties, which can be attributed to the presence of nanocrystalline $\mathrm{SiC}$ and $\mathrm{Si}_{3} \mathrm{~N}_{4}$ surrounded by turbostratic $\mathrm{BN}(\mathrm{C})$ segregations. ${ }^{13,15,17-19}$ These inhibit the thermodynamically favored decomposition of the $\mathrm{Si}-\mathrm{B}-\mathrm{C}-\mathrm{N}$ ceramics kinetically. Therefore, the multicomponent $\mathrm{Si}-\mathrm{B}-\mathrm{C}-\mathrm{N}$ ceramics are interesting materials for high-temperature applications in industry.

Moreover, we have shown that solutions of polymers containing the elements silicon, boron, carbon, nitrogen and hydrogen of convenient viscosity are applicable for coatings on non-oxide composite materials in order to protect the substrate efficiently from oxidation and corrosion, especially at very high temperatures. ${ }^{20-22}$

In this study, we describe two different syntheses and the plastic-forming and high-temperature behavior of a new class of $\mathrm{Si}-\mathrm{B}-\mathrm{C}-\mathrm{N}$ precursors, the boron-modified polysilylcarbodi-imides. In contrast to known $\mathrm{Si}-\mathrm{B}-\mathrm{C}-\mathrm{N}$ precursors, these compounds consist of repeating $\mathrm{Si}-\mathrm{N}=\mathrm{C}=\mathrm{N}$ units, which are crosslinked by $\mathrm{C}-\mathrm{B}-\mathrm{C}$ bridges. ${ }^{23,24}$ Depending on the monomeric starting compounds $\left(\mathrm{H}_{2} \mathrm{C}=\mathrm{CH}\right)(\mathrm{R}) \mathrm{SiCl}_{2} \quad\left(\mathrm{R}=\mathrm{H}, \mathrm{CH}_{3}, \mathrm{Cl}\right)$ and the reaction pathway applied, ceramic materials with various compositions, microstructures and thermal behaviors are obtained.

\section{PRECURSOR SYNTHESIS}

\section{Synthesis of vinyl-substituted polysilylcarbodi-imides}

We showed previously that boron-modified polysilylcarbodi-imides are accessible by different reaction sequences. ${ }^{23,24} \mathrm{~A}$ possible synthesis of the title compounds $\left\{\mathrm{B}\left[\mathrm{C}_{2} \mathrm{H}_{4} \mathrm{Si}(\mathrm{R}) \mathrm{NCN}\right]_{3}\right\}_{n}[\mathbf{2 a}$, $\left.\mathrm{R}=\mathrm{H} ; \mathbf{2} \mathbf{b}, \mathrm{R}=\mathrm{CH}_{3} ; \mathbf{2 c}, \mathrm{R}=(\mathrm{NCN})_{0.5}\right]$ is given by hydroboration of vinylated polysilylcarbodi-imides of the $\left[\left(\mathrm{H}_{2} \mathrm{C}=\mathrm{CH}\right)(\mathrm{R}) \mathrm{SiNCN}\right]_{n}$ type $(\mathrm{R}=$ singly bonded organic ligand) with suitable borane compounds, e.g. borane dimethylsulfide, $\mathrm{BH}_{3} * \mathrm{~S}\left(\mathrm{CH}_{3}\right)_{2}$. The syntheses of vinyl-substituted polysilylcarbodi-imides $\quad\left[\left(\mathrm{H}_{2} \mathrm{C}=\mathrm{CH}\right)(\mathrm{R}) \mathrm{SiNCN}\right]_{n}$ $\left[\mathbf{1 a}, \mathrm{R}=\mathrm{H} ; \mathbf{1 b}, \mathrm{R}=\mathrm{CH}_{3} ; \mathbf{1 c}, \mathrm{R}=(\mathrm{NCN})_{0.5}\right]$ themselves, which have been described previously for compound $\mathbf{1 b},{ }^{25,26,27}$ can be performed by the reaction of $\left(\mathrm{H}_{2} \mathrm{C}=\mathrm{CH}\right)(\mathrm{R}) \mathrm{SiCl}_{2}\left(\mathrm{R}=\mathrm{H}, \mathrm{CH}_{3}, \mathrm{Cl}\right)$ with $\mathrm{H}_{2} \mathrm{~N}-\mathrm{C} \equiv \mathrm{N}$ in the presence of pyridine (Py) in tetrahydrofuran (THF) solution, Eqn [1].

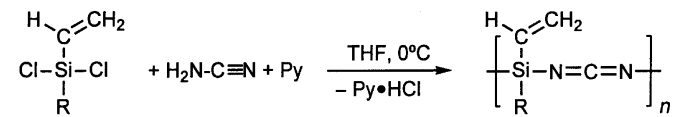

$$
\begin{aligned}
& \mathrm{R}=\mathrm{H}, \mathrm{CH}_{3}, \mathrm{Cl} \quad \text { 1a R }=\mathrm{H} \\
& \begin{aligned}
& 1 \mathrm{R} R=\mathrm{CH}_{3} \\
&1 \mathrm{NCN})_{0.5}
\end{aligned}
\end{aligned}
$$

Therefore, the vinylchlorosilanes are dissolved in THF and a pyridine/cyanamide solution is added carefully at $0^{\circ} \mathrm{C}$. After appropriate work-up, the polysilylcarbodi-imides $\mathbf{1 a - 1 c}$ are obtained as colorless waxy solids $(\mathbf{1 a}, \mathbf{1 b})$ and as a colorless powder (1c). Whereas $\mathbf{1 a}$ and $\mathbf{1 b}$ can be isolated in high yields (1a, 85\%; 1b, 78\%), the maximum yield for the polysilylcarbodi-imide 1c was $15 \%$ via this reaction sequence. This is possibly caused by the higher crosslinkage and therefore the lower solubility of this precursor compared with polymers 1a and $\mathbf{1 b}$. This finally results in a significant product loss during the filtration.

Furthermore, compounds $\mathbf{1 a - 1 c}$ are also available by the reaction of bis(trimethylsilyl)carbodiimide, which itself was synthesized from cyanamide, trimethylchlorosilane and pyridine, with the corresponding vinylchlorosilanes $\left(\mathrm{H}_{2} \mathrm{C}=\mathrm{CH}\right)(\mathrm{R})$ $\mathrm{SiCl}_{2}$ (Eqn [2]). As-obtained bis(trimethylsilyl) carbodi-imide contains traces of pyridine which catalyze the trans-silylation adequately. In comparison, the use of pure bis(trimethylsilyl)carbodiimide is less effective for this reaction. Hence, the reaction times increase considerably.

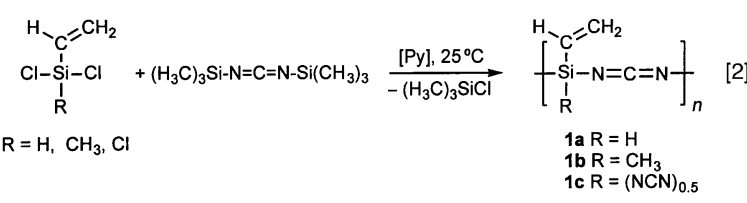

We have shown that this trans-silylation reaction can be carried out under different conditions. Performing the synthesis of compounds 1a-1c in toluene solutions results in the precipitation of the products as colorless powders (1a, 70\%; 1b, 58\%; 1c, $78 \%$ ). Therefore, the reaction mixtures have to be refluxed for seven days or longer.

Much more convenient is the synthesis of compounds 1a-1c without solvent. The educts are carefully mixed at room temperature, even stoichiometrically [1a, 1b, 1 mol bis(trimethylsilyl)- 
carbodi-imide per mol $\left(\mathrm{H}_{2} \mathrm{C}=\mathrm{CH}\right)(\mathrm{R}) \mathrm{SiCl}_{2} ; 1$ c, 1.5 mol bis(trimethylsilyl)carbodi-imide per mol $\left(\mathrm{H}_{2} \mathrm{C}=\mathrm{CH}\right) \mathrm{SiCl}_{3}$ ] or with a slight excess of bis(trimethylsilyl)carbodi-imide and stirred for an additional three hours. To quantify the reaction, the material is then slowly heated to $90^{\circ} \mathrm{C}$ to distill off built-up trimethylchlorosilane. To remove residual $\left(\mathrm{H}_{3} \mathrm{C}\right)_{3} \mathrm{SiCl}$ and possibly excess bis(trimethylsilyl)carbodi-imide, the as-obtained polymers are finally dried at $70^{\circ} \mathrm{C}$ in high vacuum. The yields of the products are $80 \%(\mathbf{1 a}), 87 \%(\mathbf{1 b})$ and $85 \%(\mathbf{1 c}) .^{23}$

These investigations indicate that the syntheses of compounds of the $\left[\left(\mathrm{H}_{2} \mathrm{C}=\mathrm{CH}\right)(\mathrm{R}) \mathrm{SiNCN}\right]_{n}$ type $\left[\mathbf{1 a}, \mathrm{R}=\mathrm{H} ; \mathbf{1 b}, \mathrm{R}=\mathrm{CH}_{3} ; \mathbf{1 c}, \mathrm{R}=(\mathrm{NCN})_{0.5}\right]$ are best performed by reacting the chlorosilanes $\left(\mathrm{H}_{2} \mathrm{C}=\mathrm{CH}\right)(\mathrm{R}) \mathrm{SiCl}_{2}$ and bis(trimethylsilyl)carbodiimide without solvent even though the syntheses of 1a-1c by the reaction of cyanamide and the chlorosilanes are somewhat cheaper. The main advantages of the trans-silylation reactions, compared with the synthesis of the polysilylcarbodiimides by a salt-elimination process, are the simplified work-up and the possibility of isolating the more highly crosslinked polymer 1c in outstanding yields. This, and especially the possibility of avoiding use of solvent, make these reactions interesting for industrial applications.

\section{Synthesis of Si-B-C-N precursors from polysilylcarbodi-imides}

The as-obtained polysilylcarbodi-imides carry vinyl units which can easily be hydroborated with suitable borane reagents. It was found that borane dimethylsulfide adds onto the vinyl units fast and selectively; an addition onto the carbodi-imide grouping as described by Kienzle et al., who applied higher temperatures, ${ }^{2,13,14}$ could not be observed.

Therefore the vinylated polysilylcarbodi-imides were dissolved $(\mathbf{1 a}, \mathbf{1 b})$ or suspended (1c) in toluene/THF, and a $2 \mathrm{M}$ solution of borane dimethylsulfide in toluene was added slowly at $0^{\circ} \mathrm{C}$. The reaction mixtures clouded immediately and the products $\left\{\mathrm{B}\left[\mathrm{C}_{2} \mathrm{H}_{4} \mathrm{Si}(\mathrm{R}) \mathrm{NCN}\right]_{3}\right\}_{n}[\mathbf{2 a}, \mathrm{R}=\mathrm{H} ; \mathbf{2 b}$, $\mathrm{R}=\mathrm{CH}_{3} ; \mathbf{2 c}, \mathrm{R}=(\mathrm{NCN})_{0.5}$ ] were directly precipitated from these solutions due to their high degree of crosslinkage (Eqn [3]). After being stirred for an additional $2 \mathrm{~h}$ at $25^{\circ} \mathrm{C}$ the solvent and dimethylsulfide could be removed in high vacuum to yield the boron-modified polysilylcarbodi-imides quantitatively as colorless powders. No further work-up was performed.

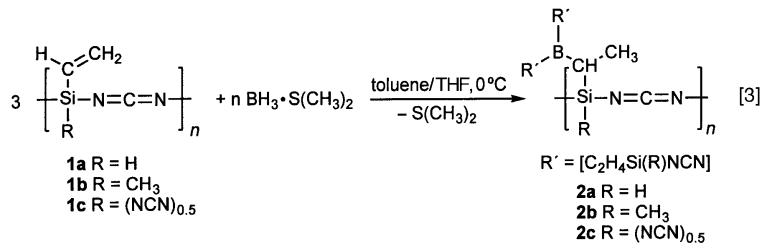

The less reactive amine trialkylamides of general type $\mathrm{R}_{3} \mathrm{~N} * \mathrm{BH}_{3}\left(\mathrm{R}=\mathrm{H}, \mathrm{CH}_{3}, \mathrm{C}_{2} \mathrm{H}_{5}\right)$ could also be used, but in this case the reaction times increased considerably and for a complete permutation the reaction mixtures had to be refluxed over a period of several days.

The structures of the boron-modified polysilylcarbodi-imides obtained from the vinyl-substituted polymers $\left[\left(\mathrm{H}_{2} \mathrm{C}=\mathrm{CH}\right)(\mathrm{R}) \mathrm{SiNCN}_{n}[\mathbf{1 a}, \mathrm{R}=\mathrm{H} ; \mathbf{1 b}\right.$, $\left.\mathrm{R}=\mathrm{CH}_{3} ; \quad \mathbf{1 c}, \mathrm{R}=(\mathrm{NCN})_{0.5}\right]$ could be assigned unequivocally by spectroscopic methods. Whereas the $\mathrm{C}=\mathrm{C}$ stretching vibrations in the FT IR spectra of compounds 1a-1c are observed at approx. $1595 \mathrm{~cm}^{-1}$, these absorption signals are not found in the corresponding product spectra. Moreover, compounds 2a-2c show very strong absorption signals for the asymmetric stretching of the carbodi-imide groupings at 2236 (1a), 2232 (1b) and $2168 \mathrm{~cm}^{-\mathrm{P}}(\mathbf{1 c})$, respectively. This indicates that the hydroboration takes place exclusively at the vinyl units. Neither addition to the $\mathrm{N}=\mathrm{C}=\mathrm{N}$ grouping nor B-H stretching absorption is observed by this spectroscopic method. Similar observations can be made in the ${ }^{13} \mathrm{C}\left\{{ }^{1} \mathrm{H}\right\}$ CP-MAS (cross-polarization/magic angle spinning) NMR spectra. While the olefinic carbon atoms of compounds 1a-1c show resonance signals at approx. $130-135 \mathrm{ppm}$, the signals of the corresponding carbon atoms of the boron-modified products $\mathbf{2 a - 2 c}$ are found at approx. $5.0\left(\mathrm{CH}_{3}\right), 10.0\left(\mathrm{CH}_{2}\right)$ and $25.0 \mathrm{ppm}$ $(\mathrm{CH})$, whereby the boron-bonded carbon atoms are detected with the typical line broadening. Moreover, an addition of the hydroboration reagent borane dimethylsulfide to the carbodi-imide unit, which would directly be reflected in a chemical shift of the carbodi-imide carbons in 1a-1c at approx. $122-125 \mathrm{ppm}$ to higher field, is not observed.

\section{Synthesis of Si-B-C-N precursors from tris[(chlorosilyl)ethyl]boranes}

An alternative process which finally results in the formation of boron-modified polysilylcarbodi-imides involves reaction of tris[(chlorosilyl)ethyl]boranes $^{28}$ of the general type $\mathrm{B}\left[\mathrm{C}_{2} \mathrm{H}_{4} \mathrm{Si}(\mathrm{R}) \mathrm{Cl}_{2}\right]_{3}(3)$ with bis(trimethylsilyl)carbodi-imide. ${ }^{23,24}$ The pro- 
ducts $\mathbf{3}$ are available on adding a toluene solution of borane dimethylsulfide, borane trimethylamide or borane triethylamide to the corresponding vinylated chlorosilanes $\left(\mathrm{H}_{2} \mathrm{C}=\mathrm{CH}\right)(\mathrm{R}) \mathrm{SiCl}_{2}\left(\mathrm{R}=\mathrm{H}, \mathrm{CH}_{3}, \mathrm{Cl}\right)$ in a 1:3 molar ratio (Eqn [4]). After distillation in vacuum $\left(10^{-2}\right.$ mbar: 3a, $102^{\circ} \mathrm{C} ; \mathbf{3 b}, 105^{\circ} \mathrm{C} ; \mathbf{3 c}$, $\left.115^{\circ} \mathrm{C}\right)$, compounds $\mathrm{B}\left[\mathrm{C}_{2} \mathrm{H}_{4} \mathrm{Si}(\mathrm{R}) \mathrm{Cl}_{2}\right]_{3}(3 \mathbf{a}, \mathrm{R}=\mathrm{H}$; 3b, $\mathrm{R}=\mathrm{CH}_{3} ; \mathbf{3 c}, \mathrm{R}=\mathrm{Cl}$ ) are obtained as colorless, highly air-sensitive oils in $95 \%$ yield.

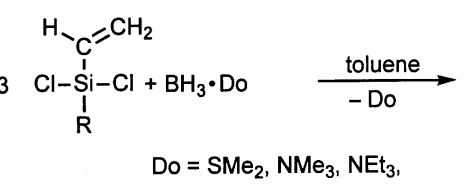

disadvantage of the former process is the slow reaction rate. Against this, reaction of the educts without solvent occurs immediately and has finished in special cases within a few minutes. In a series of experiments it was found that the reaction time depends on the one hand on the tris[(chlorosilyl)ethyl]borane used: the reactivity of the starting compounds $\mathrm{B}\left[\mathrm{C}_{2} \mathrm{H}_{4} \mathrm{Si}(\mathrm{R}) \mathrm{Cl}_{2}\right]_{3}$ towards bis(trimethylsilyl)carbodi-imide increases with respect to the substituent $\mathrm{R}$ in the order $\mathrm{CH}_{3}<\mathrm{H}<\mathrm{Cl}$. Additionally, the reaction time is strongly influenced by the temperature applied and the size of the batch, so the latter has a direct effect upon the former: with increasing batch size, effective cooling of the viscous reaction mixture becomes more difficult. This finally results in a higher reaction temperature, which is directly reflected in an increased reaction rate.

In contrast to the well-known hydroboration of olefinic hydrocarbons, the addition of $\mathrm{B}-\mathrm{H}$ to a silylated olefin is not regioselective. ${ }^{28}$ This is demonstrated in the NMR spectra of compounds $\mathbf{3 a}-\mathbf{3 c}$, which are obtained as mixtures of isomers. Depending on the silicon-bonded substituent R, $\alpha$ and $\beta$-hydroboration both take place to various extents, directly reflected in the multiplet character of the $\mathrm{CH}, \mathrm{CH}_{2}$ and $\mathrm{CH}_{3}$ resonance signals in the ${ }^{1} \mathrm{H}$ NMR and ${ }^{13} \mathrm{C}\left\{{ }^{1} \mathrm{H}\right\}$ NMR spectra in which the boron-bonded carbon atoms once more show the typical line broadening as mentioned above. The lower regioselectivity of the hydroboration of vinyl-substituted silanes compared with terminal olefinic hydrocarbons, which can result in the formation of $\alpha \alpha \alpha-, \alpha \alpha \beta-, \alpha \beta \beta$ - and $\beta \beta \beta$-hydroboration products, can also be observed in the ${ }^{29} \mathrm{Si}\left\{{ }^{1} \mathrm{H}\right\}$ NMR spectra. Moreover, the $\alpha \alpha \alpha-$ and $\alpha \alpha \beta$ products exist as diastereotopic isomers which can also be distinguished in the NMR spectra. As an example, $\mathrm{B}\left[\mathrm{C}_{2} \mathrm{H}_{4} \mathrm{SiHCl}_{2}\right]_{3} \quad$ (3a) obtained from $\left(\mathrm{H}_{2} \mathrm{C}=\mathrm{CH}\right) \mathrm{SiHCl}_{2}$ shows resonance signals at -6.5 to $-7.9 \mathrm{ppm}$ ( $\mathrm{Si}-\mathrm{CH}_{2}, \beta$-hydroboration) and at approx. 10.3 to 11.6 and 15.0 to $16.1 \mathrm{ppm}$ $\left(\mathrm{CHCH}_{3}, \alpha\right.$-hydroboration $){ }^{23}$

The pyridine-catalyzed synthesis of the boronmodified compounds $\left\{\mathrm{B}\left[\mathrm{C}_{2} \mathrm{H}_{4} \mathrm{Si}(\mathrm{R}) \mathrm{NCN}\right]_{3}\right\}_{n}[\mathbf{2 a}$, $\left.\mathrm{R}=\mathrm{H} ; \mathbf{2 b}, \mathrm{R}=\mathrm{CH}_{3} ; \mathbf{2 c}, \mathrm{R}=(\mathrm{NCN})_{0.5}\right]$ from the reaction of the tris[(chlorosilyl)ethyl]boranes $\mathbf{3 a}-\mathbf{3 c}$ and a slight excess of bis(trimethylsilyl)carbodiimide (Eqn [5]) can be performed under various conditions. Whereas their reaction in boiling toluene solution leads to the precipitation of the precursors as colorless powders, the reaction without solvent results in the formation of compounds 3a-3c as hard, glass-like materials. The greatest

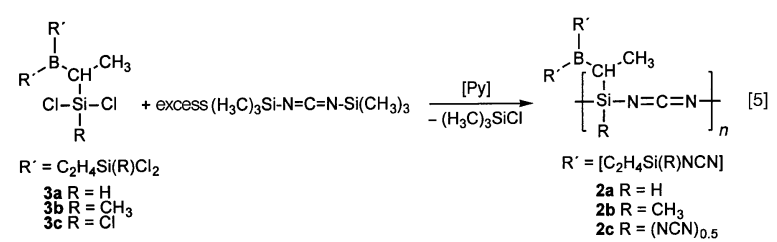

Riedel and co-workers investigated in detail the reaction coordinates of this kind of non-oxide solgel process for the synthesis of $\mathrm{Si}-\mathrm{C}-\mathrm{N}$ ceramic precursors from chlorosilanes and bis(trimethylsilyl)carbodi-imide. ${ }^{29-32}$ However, in this study the concentration of pyridine was identical in all experiments (bis[trimethylsilyl]carbodi-imide is obtained by the reaction of chlorotrimethylsilane, cyanamide and pyridine and therefore contains $0.5-$ $1 \mathrm{~mol} \%$ of the catalyst).

With respect to possible industrial applications of the boron-modified precursors, it should be mentioned that in addition to the very short reaction times observed for the synthesis of the polymers $\left\{\mathrm{B}\left[\mathrm{C}_{2} \mathrm{H}_{4} \mathrm{Si}(\mathrm{R}) \mathrm{NCN}\right]_{3}\right\}_{n}$ from $\mathbf{2 a}-\mathbf{2 c}$, and the elimination of the need for solvents, an attractive property of the whole process is that it works without waste; the chlorotrimethylsilane eliminated and the excess bis(trimethylsilyl)carbodi-imide can be recycled efficiently by distillation after the reactions have finished.

Compounds $\left\{\mathrm{B}\left[\mathrm{C}_{2} \mathrm{H}_{4} \mathrm{Si}(\mathrm{R}) \mathrm{NCN}\right]_{3}\right\}_{n}[\mathbf{2 a}, \mathrm{R}=\mathrm{H}$; $\mathbf{2 b}, \mathrm{R}=\mathrm{CH}_{3} ; \mathbf{2 c}, \mathrm{R}=(\mathrm{NCN})_{0.5}$ ] were identified by various spectroscopic methods and elemental analysis. First, solid-state ${ }^{13} \mathrm{C}\left\{{ }^{1} \mathrm{H}\right\}$ CP-MAS NMR spectra of compounds $\mathbf{2 a}-\mathbf{2} \mathbf{c}$ each depicted the resonance signal of the carbodi-imide carbon atoms at approx. $125 \mathrm{ppm}$ (Table 1). This is very close to the resonances obtained for the boron-free 
Table 1 CP-MAS NMR data (ppm) of compounds $\mathbf{2 a - 2 c}$ obtained from bis(trimethylsilyl)carbodi-imide and $\mathrm{B}\left[\mathrm{C}_{2} \mathrm{H}_{4} \mathrm{Si}(\mathrm{R}) \mathrm{Cl}_{2}\right]_{3}$

\begin{tabular}{lcccc}
\hline & & 2a & 2b & 2c \\
\hline${ }^{13} \mathrm{C}\left\{{ }^{1} \mathrm{H}\right\}$ NMR & $\mathrm{N}=C=\mathrm{N}$ & 123.5 & 123.0 & 125.8 \\
& $\mathrm{CH}$ & 24.1 & 26.6 & - \\
& $\mathrm{CH}_{2}$ & 11.2 & 10.6 & 10.7 \\
${ }^{29} \mathrm{Si}\left\{{ }^{1} \mathrm{H}\right\} \mathrm{NMR}$ & $\mathrm{CH}_{3}$ & 3.0 & 5.0 & 1.7 \\
& $\mathrm{NSiC}_{3}$ & 1.0 & 2.0 & -36.2 \\
& $\mathrm{~N}_{2} \mathrm{SiCH}$ & -36.2 & -23.0 & -55.4 \\
$\mathrm{~N}_{2} S i \mathrm{C}_{2}$ & - & - & $-0.1,8.1$ & -12.1 \\
\hline
\end{tabular}

vinyl-substituted polysilylcarbodi-imides of the $\left[\left(\mathrm{H}_{2} \mathrm{C}=\mathrm{CH}\right)(\mathrm{R}) \mathrm{SiNCN}_{n}\right.$ type as well as those of the $\mathrm{CH}_{3}, \mathrm{CH}_{2}$ and $\mathrm{CH}$ carbonatoms of the borated $\mathrm{C}_{2} \mathrm{H}_{4}$ unit at $0-5,10-12$ and 24-27 ppm (Table 1). Terminal $\mathrm{NCN}-\mathrm{Si}\left(\mathrm{CH}_{3}\right)_{3}$ in compounds $\mathbf{2 a}-\mathbf{2} \mathbf{c}$ as well as $\mathrm{SiCH}_{3}$ in compound $\mathbf{2 b}$ overlap with $\mathrm{CH}_{3}$ from the $\mathrm{C}_{2} \mathrm{H}_{4}$ units and cannot be separated.

Second, the ${ }^{29} \mathrm{Si}\left\{{ }^{1} \mathrm{H}\right\} \mathrm{CP}-\mathrm{MAS}$ NMR spectra of the title compounds also showed the expected signals at $1-3 \mathrm{ppm}$ for terminal $\mathrm{NCN}-\mathrm{Si}\left(\mathrm{CH}_{3}\right)_{3}$ groups and the silicon atoms bound in the polymer framework in the expected area (Table 1). Surprisingly, for compound $\mathbf{2 c}$ a resonance signal was found at $-36.2 \mathrm{ppm}$ which may correspond to a silicon with an $\mathrm{HCN}_{2}$ environment. The identity of this moiety is not clarified yet.

Finally, the ${ }^{11} \mathrm{~B}\left\{{ }^{1} \mathrm{H}\right\}$ CP-MAS NMR spectra of the boron-modified compounds $\mathbf{2 a - 2 c}$ show resonances at approx. -12 to $+8 \mathrm{ppm}$.

Moreover, FT IR spectroscopy identified the different functional groups in compounds $\mathbf{2 a - 2 c}$, confirming the proposed structures of the isolated boron-modified polysilylcarbodi-imides. The most remarkable absorption signals detected are $v(\mathrm{C}-\mathrm{H})$, $v_{\text {as }}(\mathrm{N}=\mathrm{C}=\mathrm{N}), v(\mathrm{Si}-\mathrm{H})(\mathbf{2 a}), \delta\left(\mathrm{CH}_{3}\right), v(\mathrm{Si}-\mathrm{C})$ and (B-C) (Table 2). Signals for $\mathrm{Si}-\mathrm{Cl}, \mathrm{C}=\mathrm{C}, \mathrm{B}-\mathrm{H}$ or B$\mathrm{N}$ vibrations, which would indicate unintended side-reactions or non-quantitative educt-to-polymer conversions, were not observed.

\section{THERMOGRAVIMETRIC INVESTIGATIONS}

The thermal conversion of elementorganic polymers into ceramics usually results in amorphous materials (see, for example, Refs 13-16 and 3338). During this process, the oligomeric or polymeric precursors decompose with elimination of gaseous species. For the production of dense precursor-derived bulk ceramics, it is of interest to design the preceramics so that the mass loss during thermolysis is low, in order to inhibit the appearance of cracks and to minimize open porosity.

The polymer-to-ceramic conversion was monitored using thermogravimetric analysis (TGA), which was performed in a purified argon atmosphere in the temperature range $25-1100^{\circ} \mathrm{C}$ (heating rate $2^{\circ} \mathrm{C} \min ^{-1}$, Figs 1 and 2) for compounds $\left[\left(\mathrm{H}_{2} \mathrm{C}=\mathrm{CH}\right)(\mathrm{R}) \mathrm{SiNCN}\right]_{n} \quad[\mathbf{1 a}, \mathrm{R}=\mathrm{H}$; 1b, $\mathrm{R}=\mathrm{CH}_{3} ; \mathbf{1 c}, \mathrm{R}=(\mathrm{NCN})_{0.5}$ ] obtained from $\left(\mathrm{H}_{2} \mathrm{C}=\mathrm{CH}\right)(\mathrm{R}) \mathrm{SiCl}_{2}$ and $\left(\mathrm{H}_{3} \mathrm{C}\right)_{3} \mathrm{SiN}=\mathrm{C}=\mathrm{NSi}\left(\mathrm{CH}_{3}\right)_{3}$

Table 2 Selected FT IR data $\left(\mathrm{cm}^{-1}\right)^{\mathrm{a}}$ of compounds $\mathbf{2 a - 2 c}$ (in $\mathrm{KBr}$ ) obtained from bis(trimethylsilyl)carbodi-imide and $\mathrm{B}\left[\mathrm{C}_{2} \mathrm{H}_{4} \mathrm{Si}(\mathrm{R}) \mathrm{Cl}_{2}\right]_{3}$

\begin{tabular}{lccc}
\hline & $\mathbf{2 a}$ & $\mathbf{2 b}$ & $\mathbf{2 c}$ \\
\hline$v(\mathrm{C}-\mathrm{H})$ & $2961(\mathrm{~m}), 2873(\mathrm{w})$ & $2963(\mathrm{~m}), 2880(\mathrm{w})$ & $2962(\mathrm{~m}), 2877(\mathrm{w})$ \\
$v_{\mathrm{as}}(\mathrm{N}=\mathrm{C}=\mathrm{N})$ & $2236(\mathrm{vs}, \mathrm{br})$ & $2232(\mathrm{vs})$ & $2179(\mathrm{vs}, \mathrm{vbr})$ \\
$v(\mathrm{~N}=\mathrm{C}=\mathrm{N})$ & $1578(\mathrm{~m})$ & $1560(\mathrm{~m})$ & - \\
$v(\mathrm{Si}-\mathrm{H})$ & $2171(\mathrm{vs}, \mathrm{br})$ & - & $1487(\mathrm{~m})$ \\
$\delta(\mathrm{CH})$ & $1457(\mathrm{~m})$ & $1260(\mathrm{~m}), 788(\mathrm{~s})$ & $1255(\mathrm{~m}), 770(\mathrm{vs})$ \\
$v(\mathrm{Si}-\mathrm{C})$ & $1260(\mathrm{~m}), 756(\mathrm{~s})$ & $1051(\mathrm{~m})$ & $1164(\mathrm{~m})$ \\
$v(\mathrm{~B}-\mathrm{C})$ & $1090(\mathrm{br})$ & - & -
\end{tabular}

a Intensity in parentheses. 


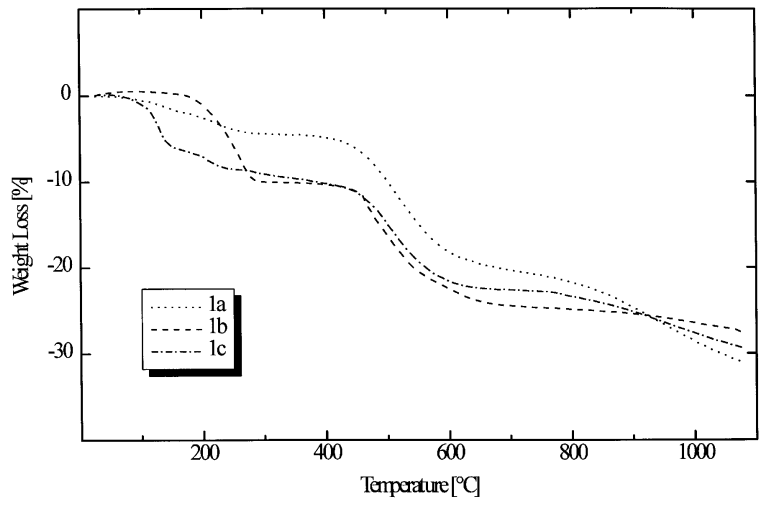

Figure 1 Thermogravimetric analysis of $\left[\left(\mathrm{H}_{2} \mathrm{C}=\mathrm{CH}\right)(\mathrm{R})\right.$ $\mathrm{SiNCN}]_{n}\left[\mathbf{1 a}, \mathrm{R}=\mathrm{H} ; \mathbf{1 b}, \mathrm{R}=\mathrm{CH}_{3} ; \mathbf{1 c}, \mathrm{R}=(\mathrm{NCN})_{0.5}\right]$; heating rate $2^{\circ} \mathrm{C} \min ^{-1}$, argon.

as well as for compounds $\left\{\mathrm{B}\left[\mathrm{C}_{2} \mathrm{H}_{4} \mathrm{Si}(\mathrm{R}) \mathrm{NCN}\right]_{3}\right\}_{n}$ $\left[\mathbf{2 a}, \mathrm{R}=\mathrm{H} ; \mathbf{2} \mathbf{b}, \mathrm{R}=\mathrm{CH}_{3} ; \mathbf{2} \mathbf{c}, \mathrm{R}=(\mathrm{NCN})_{0.5}\right]$ synthesized by the reaction of $\mathrm{B}\left[\mathrm{C}_{2} \mathrm{H}_{4} \mathrm{Si}(\mathrm{R}) \mathrm{Cl}_{2}\right]_{3}$ (3a, $\left.\quad \mathrm{R}=\mathrm{H} ; \quad \mathbf{3 b}, \quad \mathrm{R}=\mathrm{CH}_{3} ; \quad \mathbf{3 c}, \quad \mathrm{R}=\mathrm{Cl}\right) \quad$ and $\left(\mathrm{H}_{3} \mathrm{C}\right)_{3} \mathrm{SiN}=\mathrm{C}=\mathrm{NSi}\left(\mathrm{CH}_{3}\right)_{3}$.

The thermal behavior of compounds 1a-1c (Fig. 1) is very similar and results in two-step decompositions of these compounds. The ceramic yields are (1a) $71 \%$, (1b) $73 \%$ and (1c) 69\%. In the temperature range $150-250^{\circ} \mathrm{C}$, mass losses of $5 \%$ (1c) and $10 \%(\mathbf{1 a}, \mathbf{1 b})$ are observed which are mainly caused by the elimination of hydrogen and hydrocarbons as identified by TG-MS studies. At temperatures around $450-650^{\circ} \mathrm{C}$, elimination of nitrogen and cyanogen $\left(\mathrm{C}_{2} \mathrm{~N}_{2}\right)$ takes place.

Even though the compositions of the preceramic polymers are different, the mass losses of compounds 1a-1c in this temperature range are comparable (1a, 13\%; 1b, 15\%; 1c, $16 \%)$. It is remarkable that at temperatures above $900^{\circ} \mathrm{C}$ the elimination of nitrogen as well as of cyanogen is again observed.

In contrast to compounds 1a-1c, for which the thermolyses take place in two steps, the thermal behavior of compounds $\mathbf{2 a - 2} \mathbf{c}$ is characterized by a continuous mass loss over the full temperature range from 25 to $1100^{\circ} \mathrm{C}$. The ceramic yields of these polymers are lower $(\mathbf{2 a}, 63 \%$; $2 \mathbf{b}, 53 \%$; $\mathbf{2 c}$, $53 \%$ ) than those of the polysilylcarbodi-imides 1a1c, even though compounds $\mathbf{2 a - 2 c}$ are more highly crosslinked.

To investigate the high-temperature stability of the ceramic monoliths (monoliths were obtained by plastic forming of the preceramic polymer powders and then subsequently heated to $1400^{\circ} \mathrm{C}$; heating

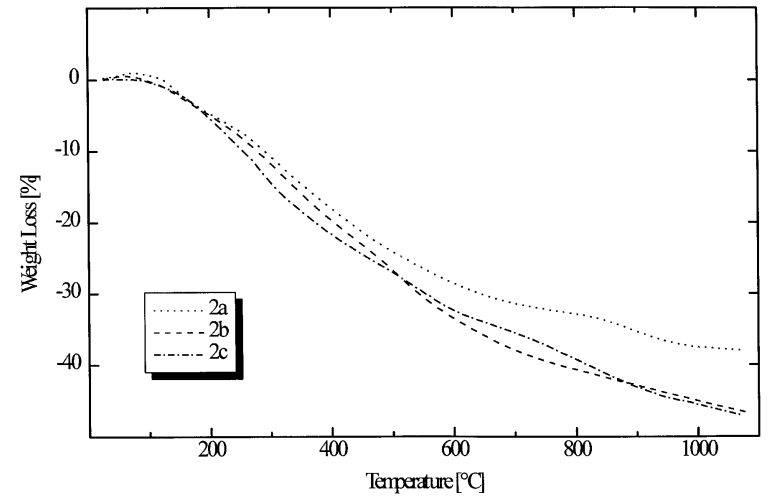

Figure 2 Thermogravimetric analysis of $\left\{\mathrm{B}\left[\mathrm{C}_{2} \mathrm{H}_{4} \mathrm{Si}(\mathrm{R})-\right.\right.$ $\left.\mathrm{NCN}_{3}\right\}_{n}\left[\mathbf{2 a}, \mathrm{R}=\mathrm{H} ; \mathbf{2} \mathbf{b}, \mathrm{R}=\mathrm{CH}_{3} ; \mathbf{2 c}, \mathrm{R}=(\mathrm{NCN})_{0.5}\right]$; heating rate, $2^{\circ} \mathrm{C} \min ^{-1}$, argon.

rate $1{ }^{\circ} \mathrm{C} \min ^{-1}$ ) obtained from compounds $1 \mathbf{a}-1 \mathbf{c}$ and 2a-2c, thermogravimetric analysis was carried out for these materials in the temperature range $25-$ $2200^{\circ} \mathrm{C}$ (argon; heating rate at $25-1200^{\circ} \mathrm{C}, 20^{\circ} \mathrm{C}$ $\min ^{-1}$, and at $1200-2100^{\circ} \mathrm{C}, 2^{\circ} \mathrm{C} \min ^{-1}$ ). The results of these investigations for the materials obtained from the boron-free polysilylcarbodiimides 1a-1c are shown in Fig. 3. Surprisingly, the molecular structure of the precursor has only a negligible influence on the thermal stability of the as-synthesized ceramic powders. (In contrast to compounds 2a-2c, intact green bodies from the boron-free polysilylcarbodi-imides $\mathbf{1 a}-\mathbf{1 c}$ have not yet been obtainable. The ceramic materials decompose at approx. $1540^{\circ} \mathrm{C}(\mathbf{1 a}, \mathbf{1 c})$ and $1570^{\circ} \mathrm{C}(\mathbf{1 b})$. This is possibly due to the decomposition of $\mathrm{Si}_{3} \mathrm{~N}_{4}$ in the presence of free carbon according to Eqn [6]. ${ }^{13,14}$ The weight losses during the thermal analyses were $25 \%$ (1a), $28 \%$ (1c) and 35\% (1b) respectively.

$$
\mathrm{Si}_{3} \mathrm{~N}_{4}+3 \mathrm{C} \stackrel{T>1440^{\circ} \mathrm{C}}{\longrightarrow} 3 \mathrm{SiC}+2 \mathrm{~N}_{2}
$$

From a few examples it is known that $\mathrm{Si}-\mathrm{C}-\mathrm{N}$ ceramics can be stabilized thermally by adding the element boron. ${ }^{1-7}$ These composites, in general obtained from the thermolysis of boron-containing polysilazanes, ${ }^{2-4}$ silylated borazine derivatives ${ }^{8-12}$ or highly crosslinked polysilazanes/borazanes, ${ }^{5-7}$ are composed of $\mathrm{Si}_{3} \mathrm{~N}_{4}, \mathrm{SiC}, \mathrm{BN}$ and free carbon. The as-obtained materials sometimes show excellent thermal stability up to $2000^{\circ} \mathrm{C}^{4,7}$ which thermodynamically cannot be sufficiently explained. It is supposed that the incorporation of boron leads to a stabilization of the amorphous state 


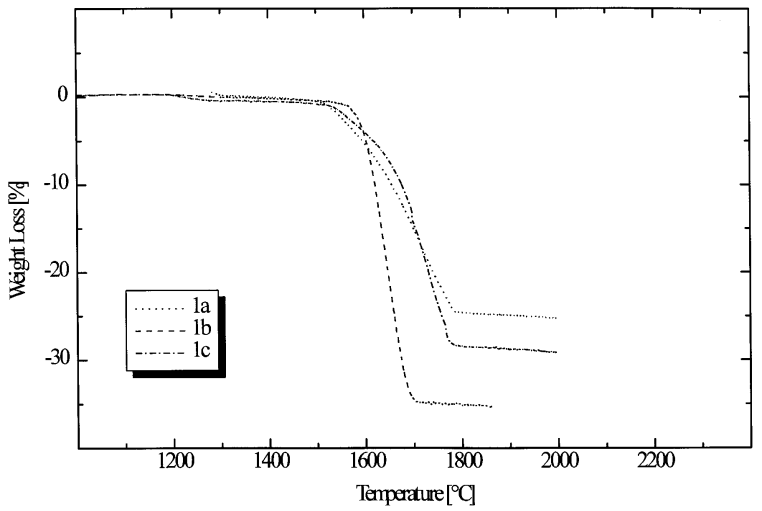

Figure 3 High-temperature thermogravimetric analysis of the ceramics obtained from $\left[\left(\mathrm{H}_{2} \mathrm{C}=\mathrm{CH}\right)(\mathrm{R}) \mathrm{SiNCN}_{n}[\mathbf{1 a}, \mathrm{R}=\mathrm{H}\right.$; 1b, $\mathrm{R}=\mathrm{CH}_{3} ; \mathbf{1 c}, \mathrm{R}=(\mathrm{NCN})_{0.5}$; 年eating rate at $25-1200^{\circ} \mathrm{C}$, $20^{\circ} \mathrm{C} \min ^{-1}$, and at $1200-2100^{\circ} \mathrm{C}, 2^{\circ} \mathrm{C} \min ^{-1}$, argon.

and shifts the temperature of the crystallization of the thermodynamically stable phases to higher values. High-resolution transmission electron microscopy (HRTEM) investigations carried out with a precursor-derived ceramic material obtained from the ammonolysis of $\mathrm{B}\left[\mathrm{C}_{2} \mathrm{H}_{4} \mathrm{Si}\left(\mathrm{CH}_{3}\right) \mathrm{Cl}_{2}\right]_{3}{ }^{2}$ point to the fact that (turbostratic) $\mathrm{BN}(\mathrm{C})$ segregations, which surround nanosized crystalline areas of $\mathrm{SiC}$ and $\mathrm{Si}_{3} \mathrm{~N}_{4}$, inhibit diffusion processes efficiently. ${ }^{17,18,19}$ These processes, however, would finally lead to the thermal decomposition of $\mathrm{Si}_{3} \mathrm{~N}_{4}$.

Figure 4 depicts the results of the high-temperature thermogravimetric investigations of the ceramics obtained from the boron-modified polysilylcarbodi-imides $\mathbf{2 a - 2 c}$. It is observed that the decomposition of these materials begins around $1500^{\circ} \mathrm{C}(\mathbf{2 b}, \mathbf{2 c})$ whereas the ceramic obtained from the hydrogen-substituted precursor $\mathbf{2 a}$ starts to decompose at approx. $1600^{\circ} \mathrm{C}$. These results are comparable with those found for the boron-free materials. In conclusion, a significant increase in the thermal stability due to the modification of compounds 1a-1c with boron could not be detected. Likewise, the thermogravimetric yields, at approx. $70 \%\left(2000^{\circ} \mathrm{C}\right)$, are comparable with those of the ceramics obtained from compounds 1a-1c.

As mentioned above, one can presume that the decomposition of the ceramics, whether obtained from the boron-free or from the boron-modified polysilycarbodi-imides, is caused by the elimination of nitrogen. In Fig. 4 it is shown that, in a first decomposition step, mass losses of approx. 25\% $(\mathbf{2 a}, \mathbf{2 c})$ and $28 \%(\mathbf{2 b})$ are detected. These findings

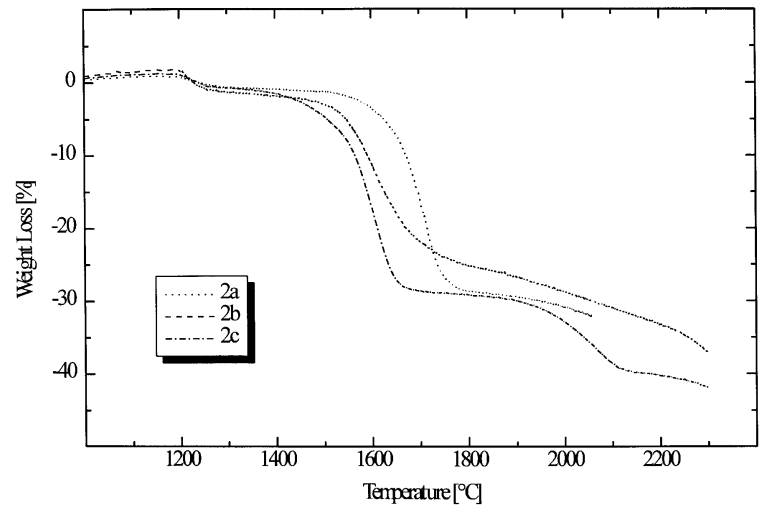

Figure 4 High-temperature thermogravimetric analysis of the ceramics obtained from $\left\{\mathrm{B}\left[\mathrm{C}_{2} \mathrm{H}_{4} \mathrm{Si}(\mathrm{R}) \mathrm{NCN}_{3}\right\}_{n}[\mathbf{2 a}, \mathrm{R}=\mathrm{H} ; \mathbf{2 b}\right.$, $\mathrm{R}=\mathrm{CH}_{3} ; 2 \mathrm{c}, \mathrm{R}=(\mathrm{NCN})_{0.5}$ ]; heating rate at $25-1200^{\circ} \mathrm{C}, 20^{\circ} \mathrm{C}$ $\min ^{-1}$, and at $1200-2100^{\circ} \mathrm{C}, 2^{\circ} \mathrm{C} \mathrm{min^{-1 }}$, argon.

are in a good accord with the results of the elemental analysis performed for the ceramics obtained from $\mathbf{2 a}$ (found: $23.5 \mathrm{wt} \% \mathrm{~N}$ ), $\mathbf{2 b}$ (found: $25 \mathrm{wt} \% \mathrm{~N}$ ) and 2c (found: $23.4 \mathrm{wt} \% \mathrm{~N}$ ).

Remarkably, monoliths obtained from the title compounds did not tend to crack at temperatures up to $2300^{\circ} \mathrm{C}$ in an argon atmosphere, although the shrinkage was roughly proportional to the mass loss during thermolysis. The crystallization of these materials, investigated by X-ray diffraction (XRD), began at approx. $1650-1700^{\circ} \mathrm{C}$ and finally resulted in the formation of SiC. Crystalline phases containing boron were not observed, possibly because of the low boron contents (5-6 wt\%) of the materials.

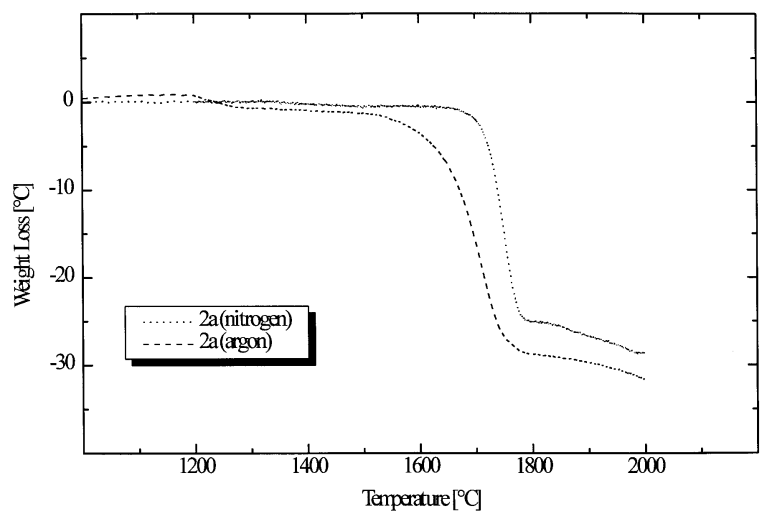

Figure 5 High-temperature thermogravimetric analysis of the ceramic obtained from $\left\{\mathrm{B}\left[\mathrm{C}_{2} \mathrm{H}_{4} \mathrm{Si}(\mathrm{H}) \mathrm{NCN}\right]_{3}\right\}_{n}(\mathbf{2 a})$ in different atmospheres; heating rate at $25-1200^{\circ} \mathrm{C}, 20^{\circ} \mathrm{C} \mathrm{min}{ }^{-1}$, and at $1200-2100^{\circ} \mathrm{C}, 2^{\circ} \mathrm{C} \min ^{-1}$.

Appl. Organometal. Chem. 12, 725-734 (1998) 
Table 3 Selected data obtained by mercury pressure porosimetry of ceramic monoliths synthesized from $\left\{\mathrm{B}\left[\mathrm{C}_{2} \mathrm{H}_{4} \mathrm{Si}(\mathrm{H}) \mathrm{NCN}_{3}\right\}_{n}\right.$ (2a)

\begin{tabular}{|c|c|c|c|c|c|c|}
\hline \multirow[b]{3}{*}{ Pressure (MPa) } & \multicolumn{6}{|c|}{ Pressing temp. $\left({ }^{\circ} \mathrm{C}\right)$} \\
\hline & \multicolumn{3}{|c|}{100} & \multicolumn{3}{|c|}{120} \\
\hline & 31.0 & 38.7 & 42.6 & 31.0 & 38.7 & 44.5 \\
\hline Spec. surface area $\left(\mathrm{m}^{2} \mathrm{~g}^{-1}\right)$ & 17.64 & 7.67 & 8.92 & 3.63 & 3.76 & 5.68 \\
\hline Average pore radius $(\mu \mathrm{m})$ & 0.028 & 0.033 & 0.033 & 0.02 & 0.011 & 0.01 \\
\hline Bulk density $\left(\mathrm{g} \mathrm{cm}^{-3}\right)$ & 1.43 & 1.72 & 1.58 & 1.93 & 1.82 & 1.68 \\
\hline Corr. bulk density $\left(\mathrm{g} \mathrm{cm}^{-3}\right)$ & 1.77 & 1.995 & 1.801 & 2.066 & 1.927 & 1.768 \\
\hline Total sample porosity $(\%)$ & 19.26 & 13.79 & 12.26 & 6.60 & 5.53 & 4.95 \\
\hline
\end{tabular}

With respect to the above-mentioned decomposition of $\mathrm{Si}_{3} \mathrm{~N}_{4}$ in the presence of free carbon, it is of general interest to investigate the influence of the atmosphere on the thermal behavior of the ceramic materials obtained. For example, a comparison was made for the ceramic obtained from the boronmodified precursor $\left\{\mathrm{B}\left[\mathrm{C}_{2} \mathrm{H}_{4} \mathrm{Si}(\mathrm{H}) \mathrm{NCN}\right]_{3}\right\}_{n}$ (2a) which is shown in Fig. 5. It is observed that in contrast to the thermal decomposition of this material which occurred in an argon atmosphere at approx. $1600^{\circ} \mathrm{C}$, thermal decomposition in nitrogen began at $1700^{\circ} \mathrm{C}$.

\section{PLASTIC FORMING OF BORON- MODIFIED POLYSILYCARBODI- IMIDES}

To obtain precursor-derived bulk ceramic materials, preceramics are in general shaped by cold isostatic pressing (CIP). The as-obtained green bodies are then transformed into amorphous ceramic monoliths by subsequent thermolysis. However, a remarkable disadvantage of this method is that it is less applicable for the densification of highly crosslinked polymer pow-

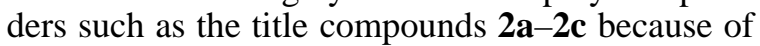
their inelastic nature. Yet a high degree of crosslinkage in the polymeric state is needed to avoid softening of the green parts during thermolysis. Therefore, plastic forming (PF), has been applied for the shaping of green bodies from boronmodified polysilylcarbodi-imide powders. ${ }^{39}$

For the determination of optimized conditions for this process, TMA investigations of the green bodies obtained by CIP were performed. These studies indicate that the title compounds soften in the range $100-180^{\circ} \mathrm{C}$, but melting is not observed. At temperatures above $180^{\circ} \mathrm{C}$ the decomposition of the precursors begins (Fig. 2). Hence, the densifica- tion of the polymer powders, which were first milled using a ball mill and then sieved (mesh size $0.16 \mathrm{~mm}$ ) in order to obtain a homogeneous grain size distribution, was achieved at temperatures around $100-150^{\circ} \mathrm{C}$ at various pressures. Accordingly the as-obtained fine-grained powders were compacted by uniaxial pressing in graphite dies and then pyrolyzed at $1400^{\circ} \mathrm{C}\left(25-1400^{\circ} \mathrm{C}\right.$, heating rate $\left.1^{\circ} \mathrm{C} \min ^{-1}\right)$ in an argon atmosphere. Due to the significant sensitivity of the boron-modified polymers towards oxygen and moisture, the complete process was carried out in an inert-gas atmosphere or in vacuum.

To investigate the microstructure of the assynthesized monoliths, scanning electron microscopy (SEM) and mercury pressure porosimetry were carried out for the ceramics obtained from compound $\left\{\mathrm{B}\left[\mathrm{C}_{2} \mathrm{H}_{4} \mathrm{Si}(\mathrm{H}) \mathrm{NCN}\right]_{3}\right\}_{n}$ (2a; Table 3, Fig. 6). The results of the mercury pressure porosimetry show that the microstructure of the precursor-derived monolith is strongly influenced by the pressing temperatures applied. Increasing the pressing temperature results in a lower specific

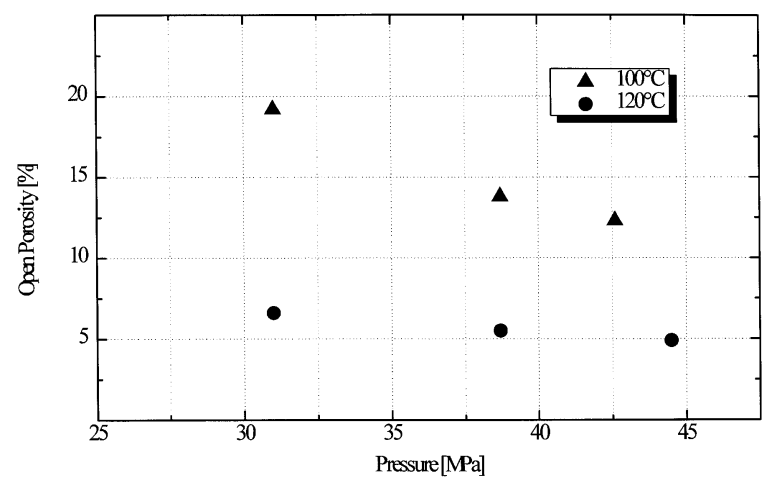

Figure 6 Correlation of pressure applied for PF and total sample porosity of ceramic monoliths obtained from $\left\{\mathrm{B}\left[\mathrm{C}_{2} \mathrm{H}_{4} \mathrm{Si}(\mathrm{H}) \mathrm{NCN}\right]_{3}\right\}_{n}$ (2a).

Appl. Organometal. Chem. 12, 725-734 (1998) 

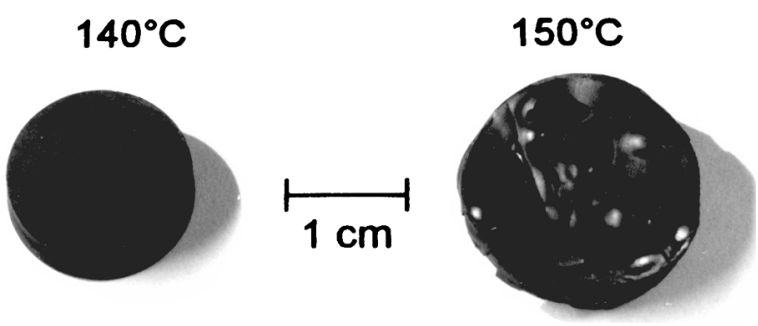

Figure 7 Ceramic monoliths, obtained by thermolysis (25$1400^{\circ} \mathrm{C}$, heating rate $1{ }^{\circ} \mathrm{C} \min ^{-1}$, argon) of $\left\{\mathrm{B}\left[\mathrm{C}_{2} \mathrm{H}_{4} \mathrm{Si}(\mathrm{H}) \mathrm{NCN}\right]_{3}\right\}_{n}$ (2a) green bodies plastic-formed at 35 $\mathrm{MPa}$ at $140^{\circ} \mathrm{C}$ and $150^{\circ} \mathrm{C}$, as indicated.

surface area as well as in a decrease of the average pore size, which is correspondingly directly reflected in an increased bulk density of the monoliths. Furthermore, the total sample porosity also decreases with increasing pressure, as expected. As depicted in Fig. 6 there is a linear correlation of the pressure applied for PF and the total sample porosity after thermolysis.

From Fig. 6 one should conclude that additionally increasing the pressing temperature and the pressure applied results in samples with further increased density and decreased porosity. With respect to the preparation of dense and crack-free ceramic monoliths it soon became clear that there is a limit to densifying the green bodies. Our

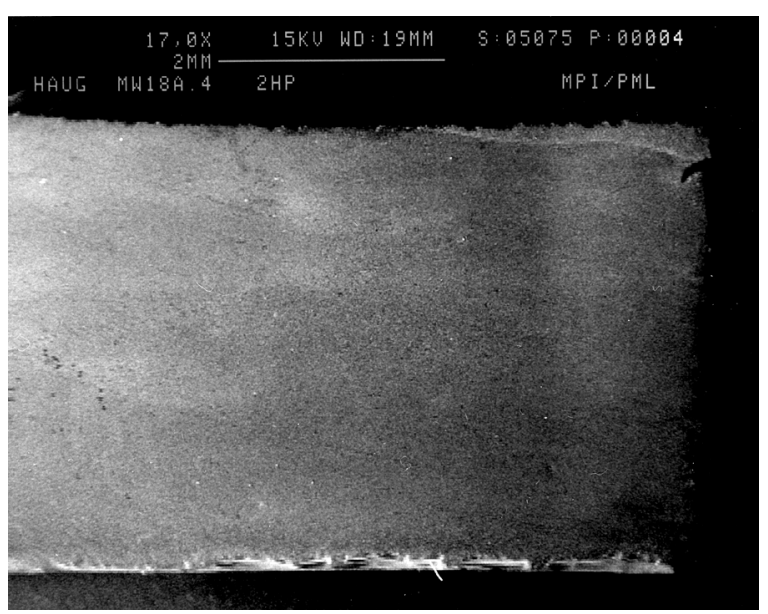

Figure 8 SEM (Magnification $\times 17$ ) of a cross-section of a ceramic monolith, obtained by thermolysis $\left(25-1400^{\circ} \mathrm{C}\right.$, heating rate $1^{\circ} \mathrm{C} \min ^{-1}$, argon) of a $\left\{\mathrm{B}\left[\mathrm{C}_{2} \mathrm{H}_{4} \mathrm{Si}(\mathrm{H}) \mathrm{NCN}\right]_{3}\right\}_{n}$ (2a) green body, plastic-formed at $140^{\circ} \mathrm{C}, 35 \mathrm{MPa}$.

(C) 1998 John Wiley \& Sons, Ltd.

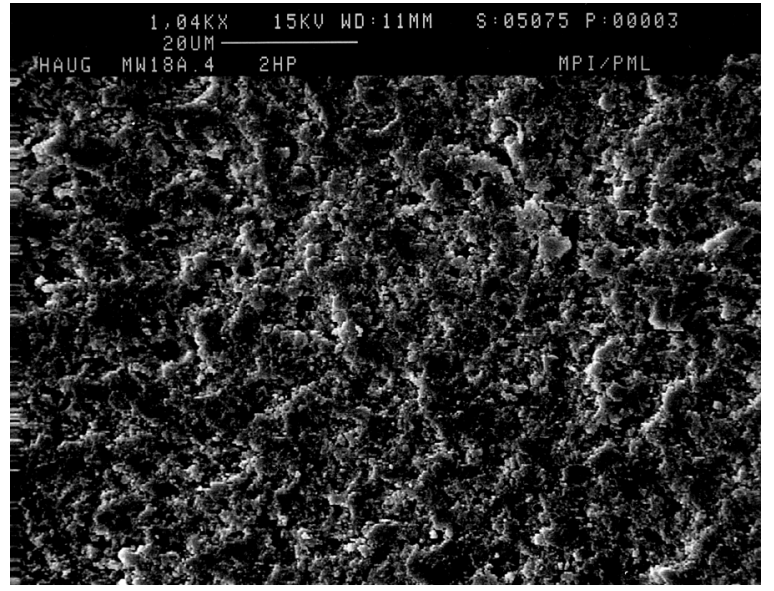

Figure 9 SEM (magnification $\times 1040)$ of a cross-section of a ceramic monolith, obtained by thermolysis $\left(25-1400^{\circ} \mathrm{C}\right.$, heating rate $1^{\circ} \mathrm{C} \min ^{-1}$, argon) of a $\left\{\mathrm{B}\left[\mathrm{C}_{2} \mathrm{H}_{4} \mathrm{Si}(\mathrm{H}) \mathrm{NCN}\right]_{3}\right\}_{n}$ (2a) green body, plastic-formed at $140^{\circ} \mathrm{C}, 35 \mathrm{MPa}$.

investigations reveal that open porosity is needed to allow the release of gaseous decomposition products during thermolysis and therefore to prevent bloating of the monoliths (Fig. 7).

SEM investigations show that ceramic monoliths obtained from boron-modified polysilylcarbodiimides possess a very homogeneous microstructure (Figs 8 and 9). Figure 8 shows a cross-section through a complete specimen which emphasizes the homogeneity of the whole bulk material. No cracks nor bubbles are observed. The impurities (white layer) at the surfaces of the material are residual boron nitride with traces of graphite. These are caused by the use of boron nitride-treated graphite dies for powder densification.

Figure 9 shows the monolith cross-section of Fig. 8 at higher magnification. The homogeneous microstructure suggests that ceramics obtained from boron-modified polysilylcarbodi-imides are suitable for the preparation of dense bulk materials.

Acknowledgments We thank the Deutsche Forschungsgemeinschaft (DFG) and the Japan Science and Technology Corporation (JST) for financial support. For many discussions we are grateful to Professor Dr Gerd Becker. Furthermore, the authors thank Sabine Katz warmly for supporting us in preparative chemistry and for carrying out the mercury pressure porosimetry. Horst Kummer is acknowledged for performing the high-temperature thermogravimetric analysis. The authors also thank Martina Thomas for performing the XRD studies and Alf Breitschwerdt for performing the FT IR analysis.

Appl. Organometal. Chem. 12, 725-734 (1998) 


\section{REFERENCES}

1. M. Takamizawa, T. Kobayashi, A. Hayashida and Y. Takeda, US Patent 4604367 (1986).

2. A. Kienzle, Thesis, Universität Stuttgart, 1994.

3. J. Bill, A. Kienzle, M. Sasaki, R. Riedel and F. Aldinger, Ceramics: Charting the Future Vincenzini, p. (ed.), 1995, p. 1291.

4. R. Riedel, A. Kienzle, W. Dressler, L. Ruwisch, J. Bill and F. Aldinger, Nature (London) 382, 796 (1996).

5. M. Jansen and H.-P. Baldus, Ger. Offer DE 4107108 A1 (1992).

6. H.-P. Baldus, O. Wagner and M. Jansen, Mater. Res. Soc. Symp. Proc. 271, 821 (1992).

7. H.-P. Baldus, M. Jansen and O. Wagner, Key Eng. Mater. 89-91, 75 (1994).

8. D. Seyferth and H. Plenio, J. Am. Ceram. Soc. 73, 2131 (1990).

9. D. Seyferth, H. Plenio, W. S. Rees Jr and K. Büchner, Silicon ceramics with a dash of Boron. In: Frontiers of Organosilicon Chemistry, The Royal Society of Chemistry, Cambridge, 1991.

10. K. Su, E. E. Remsen, G. A. Zank and L. G. Sneddon, Chem. Mater. 5, 547 (1993).

11. T. Wideman, K. Su, E. E. Remsen, G. A. Zank and L. G. Sneddon, Chem. Mater. 7, 2203 (1995).

12. T. Wideman, K. Su, E. E. Remsen, G. A. Zank and L. G. Sneddon, Mater. Res. Soc. Symp. Proc. 410, 185 (1996).

13. J. Bill and F. Aldinger, Adv. Mater. 7, 775 (1995).

14. R. Riedel, J. Bill and A. Kienzle, Appl. Organometal. Chem. 10, 241 (1996).

15. J. Bill and F. Aldinger, Z. Metallk. 87, 827 (1996).

16. H.-P. Baldus and M. Jansen, Angew. Chem., Int. Ed. Engl. 36, 328 (1997).

17. A. Jalowiecki, J. Bill, F. Aldinger and J. Mayer, Composites Part A 27, 717 (1996).

18. A. Jalowiecki, J. Bill, M. Friess, J. Mayer, F. Aldinger and R. Riedel, Nanostructured Mater. 6, 279 (1995).

19. A. Jalowiecki, Thesis, Universität Stuttgart, 1997.

20. D. Heimann, J. Bill and F. Aldinger, Fortschrittsberichte der Deutschen Keramischen Gesellschaft, WerkstoffeVerfahren-Anwendungen, Vol. 10 Keramische Schichten, 1995.

21. D. Heimann, Thesis, Universität Stuttgart, 1996.

22. M. Weinmann, A. Kienzle, D. Heimann, J. Bill and F.
Aldinger, Int. Meeting on Boron Chemistry IX (IMEBORON), Heidelberg, Germany, 1996, Book of Abstracts, p. 121.

23. M. Weinmann, R. Haug, J. Bill, F. Aldinger, J. Schuhmacher and K. Müller, J. Organometal. Chem., 541, 345 (1997).

24. M. Weinmann, presentation at Workshop on Grain Boundary Dynamics of Precursor Derived Ceramics, Schloß Ringberg, Germany, 10-15 Nov. 1996.

25. J. Pump and E. Rochow, Z. Anorg. Allg. Chem. 330, 101 (1964).

26. A. Kienzle, A. Obermeyer, R. Riedel, F. Aldinger and A. Simon, Chem. Ber. 126, 2569 (1993).

27. R. Riedel, A. Greiner, G. Miehe, W. Dreßler, H. Fue $\beta$, J. Bill and F. Aldinger, Angew. Chem., Int. Ed. Engl. 36, 384 (1997).

28. P. R. Jones and J. K. Myers, J. Organometal. Chem. 34, C9 (1972).

29. A. O. Gabriel and R. Riedel, Angew. Chem., Int. Ed. Engl. 36, 384 (1997).

30. A. O. Gabriel, R. Riedel, S. Storck and W. F. Maier, Appl. Organometal. Chem., 11, 833 (1997).

31. R. Riedel, personal communication.

32. A. Kienzle, J. Bill, F. Aldinger and R. Riedel, Nanostructured Mater. 6, 349 (1995).

33. R. M. Laine, Transformation of Organometallics into Common and Exotic Materials: Design and Activation, Proc. NATO Advanced Research Workshop, Cap D’Agde, France, 1986.

34. W. Toreki, Polym. News 16, 6 (1991).

35. D. Segal, Chemical Synthesis of Advanced Ceramic Materials, Cambridge University Press; Cambridge, 1994.

36. Y. D. Blum, K. B. Schwartz and R. M. Laine, J. Mater. Sci. 24, 1707 (1989).

37. M. Zeldin, K. J. Wynne and H. R. Allcock (eds), Inorganic and Organometallic Polymers, Advanced Materials and Intermediates, ACS Symp. Ser. No. 360, American Chemical Society, Washington, DC, 1988.

38. P. Wisian-Neilson, H. R. Allcock and K. J. Wynne (eds), Inorganic and Organometallic Polymers II, Advanced Materials and Intermediates, ACS Symp. Ser. No. 572, American Chemical Society, Washington, DC, 1994.

39. R. Haug, M. Weinmann, J. Bill and F. Aldinger, Europ. Ceram. Soc., in press. 